\title{
Zgaga, P., Teichler, U., Schuetze, H. G., Wolter, A. (Eds.) (2015). Higher Education Reform: Looking Back - Looking Forward. Frankfurt/M.: Peter Lang, 430 pp. ISBN 978-3-631-66275-5.
}

Reviewed by DARKo ŠTrAJN ${ }^{1}$

After reading this book one is bound to realise that a point of no return has been reached in higher education; still, looking back on different academic traditions - which involves memory, history and some important genealogies - is very much indispensable. However, the past cannot provide all of the answers regarding what looms as yet another reform in the near future. While a new wave of global reform is rather certain, as it were, its outcome is in many respects very unclear. From the texts in this book one can conclude that the reform will be a series of sometimes possibly antago-

Pavel Zgaga/Ulrich Teichler/Hans G. Schuetze/Andrä Wolter (eds.)

Higher Education Reform: Looking Back Looking Forward nistic confrontations between actors, players and "stakeholders". Above all, the notion of academic life and work is being transformed into a kind of myth, and there are multiple reasons for this. Among researchers in the enormously complex field of the exploration of higher education such awareness seems to be clearly accepted. The volume being examined here may well serve as evidence of the above claims. Published as Volume 8 in the series "Higher Education Research and Policy (HERP)" in Peter Lang's Edition, it is one of the results of a number of international activities such as networking, conferences and other forms of research cooperation in this crucially important field. Apart from the Introduction, the book consists of eighteen studies spread over five thematic "sections."

In the Introduction, the editors give a brief overview of the last four or five decades of changes in the domain of higher education. They emphasise the massification of higher education as one of the crucial phenomena. More recent

1 Educational Research Institut, Ljubljana, Slovenia. 
transformations in particular are, in their view, linked to the neoliberal framework that has introduced into this area monstrosities such as marketization, privatisation and rankings of universities. Along with these developments came a thoroughly changed "role of the academic profession" as well as a metamorphosis of students from "learners" to "consumers" (p. 11). On the list of decisive influences, the editors also include internationalisation, which has pushed reform to supra-national levels. Of course, the role of research has changed as well, due to the demand for evidence-based policies. The introduction provides a condensed and clear cognitive mapping of the whole field, preparing the interested reader for the very rich content that follows.

Section A (Changing Contexts and Directions) begins with Ulrich Teichler's chapter dealing with the future of higher education. After pointing to the main trends such as internationalisation, professionalization and the "incorporation of higher education into a system of life-long-learning" (p. 33), the author's analysis uncovers different possible scenarios of the future and points to open questions and dilemmas concerning already known dubious trends such as the "rate race" for success, assessment inflation, destructive competition, subordination under external demands, political pressures, and so on. Peter Scott is no less generous in exposing the impasses and paradoxes that appear when we attempt to consider the future of higher education. His chapter is a search for answers regarding the meaning of a supposed transition from mass to market higher education, with the author outlining the many uncertainties associated with the contexts and policies that produce a "confusion of roles and responsibilities" (p. 62). The last contribution in Section A, written by Pavel Zgaga, shifts the focus to the level of a particular environment. The author stresses the importance of discerning specificities in the case of South-East Europe, which cannot be simply categorised as an area of former communism. Broader historical changes have been strongly expressed in the area of higher education, which has undergone all of the aforementioned transformations, such as massification, privatisation, etc. However, local answers to challenges, especially in the "wave of reform" triggered by the Bologna process, are interesting because they demonstrate the importance of a good reading of the past in order to develop appropriate policies for the future within the global world.

After the Introductory Note by Hans G. Schuetze, in which the author clarifies some notions and concepts as well as commenting on the chapters that follow, Section B (Changing Environments and Missions of Higher Education) begins with Marek Kwiek's reflection on reforming European universities, which he connects to the reform of European welfare states. His hypothesis that "higher education will be reformed mostly from outside rather than mostly 
from the inside" is substantiated in the whole chapter by demonstrating that higher education is a part of the public sector subject to grave pressures. The next chapter, written by Shinichi Yamamoto, is a narrative on Japan's history of reform, which is also succinctly represented through tables and data. The article then focuses on recent reform in the context of the "bubble economy" crisis, the aging population and the declining number of young people. The author concludes by observing that the "reform process is continuing with no prospect of ending" (p. 130). China's higher education is marked by rather rapid massification and by the world's highest current level of enrolments. W. James Jacob and John N. Hawkins wrote their contribution on the basis of their research in China, which comprised hundreds of interviews with higher education administrators. They identified five main trends in Chinese higher education: structural reforms, finance, continuing education, mobility and quality assurance. Andrä Wolter takes a deeper look at diversity as, presumably, a result of the massification of higher education. His findings, arrived at using a great deal of evidence from "Eurostudent" research, show differences between countries in which massification has brought about changes in social mobility, gender equality, etc., and other countries in which the growth in enrolments has not transformed the structure of "academic self-reproduction". The case of Germany is emphasised in particular.

Section C deals with the exceptionally interesting topic of academic freedom. Rolf van Lüde gives a clear historically founded view on the nature of the Humboldtian concept of academic freedom and points to marketization, which installs a "new managerialism" at universities, as an influential agency that decomposes this not only German tradition. Rosalind M. O. Pritchard very vividly displays the fate of the three Humboldtian unities - of research and teaching, of teachers and learners, and of knowledge - in the British context. As she finds that the German model of academic freedom "has not fared especially well in Britain", she concludes with the claim that "The German model is more needed and could be more helpful in the reconstruction of British higher education than ever before" (p. 209). William Bruneau, who also introduced the whole section by defining the notion of academic freedom, contributes an exhaustive chapter on academic freedom in North American higher education. He writes about the five main philosophically based defences of academic freedom and, significantly, finds that the reason for their insufficiency is to be found in the "logic of the concept of utility" (p. 221). He therefore points to managerialism as "no ordinary threat", providing some specific examples that illustrate his point.

Globalisation and privatisation are the key areas of discussion in Section D. At the beginning of his Introductory Note, Germán Álvarez-Mendiola 
appropriately observes that "Markets in higher education has become predominant in the world. Gone is the era of the domination of the state and academics in university affairs" (p. 235). In co-authorship with Mitzi Danae Morales Montes, Álvarez-Mendiola has also written an overview of trends in private education in Mexico. The authors highlight governments' '"benign neglect' toward the private sector" (p. 252), while, to a degree, applauding policies of the expansion of public sector higher education in the country. Wietse de Vriesand and again Álvarez-Mendiola make use of the concept of "third degree path dependency" to analyse problems of "resistance to change" in higher education reform in Mexico's universities. The following contribution by Hans G. Schuetze is critical, but descriptive enough for the reader to grasp historical and other facts. The chapter presents an overview of higher education in Canada and the United States, with the relationship between private and public institutions being shown in the light of certain differences between the two North American federations.

Andrä Wolter introduces Section E by reflecting critically on the very meaning of the notion of "lifelong learning". Ulrich Teichler accepts that there is a need for lifelong learning, for reasons that mainly stem from changes in the areas of work and employment (due to the neoliberal rationale and economic regime), but he first finds significant discrepancies between expectations and the actual changes in the university in the 1990s, and goes on to discover new discrepancies in this respect in the $21^{\text {st }}$ century as well. Anna Spexard's chapter connects to Teichler's position and his understanding of the concept of lifelong learning. Presenting persuasive evidence, she supports the finding that political discourses on lifelong learning and the actual implementation of appropriate policies do not correspond very well to each other. However, she admits that "lifelong learning gained prominence in European policy debates" (p. 336). Spexard observes some influences within the Bologna reform process that help certain practices of lifelong learning, but concludes that there is a lack of adequate data for any definitive claim. Maria Slowey links the concept of lifelong learning to demographic problems and, consequently, to the question of access to higher education institutions. After an overview of certain significant data, she suggests ten "Principles for an Age Friendly University", which could also be read as a set of recommendations for policy making. Very instructive is yet another contribution by Andrä Wolter in the form of a case study of Germany, examining the social, economic and demographic circumstances. On the basis of ample statistical evidence and empirical facts, the author views Germany as a "delayed nation" in this respect. Finally, Maureen W. McClure analyses "Massive Open Online Courses" and conflicting narratives in higher 
education policies related to this phenomenon, which is implemented with new communication technologies. The author illustrates her point with Gartner's theory of the "Hype Cycle," which shows the rise from the "technology trigger" to the peak of inflated expectations, from which there is a fall due to disillusionment. Then comes a new slope, which reaches a "plateau of productivity." Online courses are still an open opportunity for higher education and, as the author says: "How they will be positioned within institutions matters" (p. 397).

Overall, the book makes very interesting reading, containing a great deal of high quality information, which, naturally, could not be more extensively covered in the present text. The most important aspect of the whole volume is, however, the fact that it gives voice to researchers of higher education who tend to critically contextualise their concepts, findings and data. The book as a whole quite clearly suggests that there is a serious tension between higher education institutions, their traditions and inner tendencies, on the one hand, and, on the other hand, policies that are generated by broader social developments within the framework of neoliberal trends and domination. 